\title{
MILK PRODUCTION AND REPRODUCTIVE TRAIT CAUSED BY LOC514211 GENE MUTATION IN DAIRY COWS
}

\author{
A. S. Anggraeni ${ }^{1}$, E. Kurnianto ${ }^{2}$, S. Johari ${ }^{2}$, Sutopo ${ }^{2}$ and Z. Shujun ${ }^{3}$ \\ ${ }^{1}$ Research Unit for Process Development and Chemical Engineering, \\ Indonesian Institute of Science (UPT BPPTK LIPI), Jl. Yogyakarta-Wonosari Km 31.5 Gading, \\ Playen, Gunung kidul, Yoogyakarta, 55861 - Indonesia \\ ${ }^{2}$ Faculty of Animal and Agricultural Sciences, Diponegoro University, \\ Tembalang Campus, Semarang 50275 - Indonesia. \\ ${ }^{3}$ Key Laboratory of Agricultural Animal Genetics, Huazhong Agricultural University, \\ Wuhan 430070 - China. \\ CorrespondingE-mail:ayu.anggraeni07@gmail.com \\ Received October 02, 2015; Accepted November 24, 2015
}

\begin{abstract}
ABSTRAK
SNP (rs 42688595) terletak di LOC514211, merupakan gen yang tidak terkarakterisasi dan terletak di kromosom 13 pada Bos taurus, memiliki efek yang signifikan terhadap produksi susu dan kualitas susu yang telah diidentifikasi dari sapi perah Cina dan Inggris menggunakan metode GWAS (Genome Wide Association Study) berdasarkan 60k SNP-Chip dalam penelitian sebelumnya. Tujuan penelitian ini adalah untuk mengkonfirmasi efek dari SNP di LOC514211 pada sifat produksi dalam populasi lain pada sapi perah Chinese Holstein. Empat ratus tujuh puluh sapi perah digunakan dalam penelitian ini, dilakukan ekstraksi genom DNA dari sampel darah, genotyping dilakukan dengan metode PCR-RFLP pada sampel DNA. Analisis statistik yang digunakan adalah ANOVA dengan menggunakan metode General Linear Model (GLM) SAS 9.13 untuk mengidentifikasi asosiasi SNP dengan susu dan sifatsifat reproduksi. Hasil penelitian menunjukkan bahwa SNP pada LOC514211 bersifat polimorfik dalam kelompok sapi perah ini dan terdapat ketidakseimbangan Hukum Hardy-Weinberg, serta memiliki perbedaan yang signifikan antar genotipe dalam parameter produksi susu, kualitas susu dan sifat-sifat reproduksi, yang linier dengan hasil penelitian GWAS sebelumnya yang berbasis SNP-Chips. Kesimpulan dari penelitian ini menunjukkan bahwa SNP pada LOC514211 mempunyai kecenderungan berpotensi sebagai penanda bagi sifat-sifat produksi susu dan reproduksi.
\end{abstract}

Kata kunci: SNP, LOC514211, sifat produksi susu, sifat reproduksi, sapi perah

\section{ABSTRACT}

The SNP (rs 42688595) in LOC514211 is uncharacterized gene and located in chromosome 13 in Bos taurus, had significant effects on milk yield and milk quality that have been identified from Chinese and British dairy cows using GWAS (Genome-wide Association Study) based on 60k SNP-Chip in the previous study. The objective of this study was to confirm the effects of the SNP in LOC514211 on productive traits in another population of Chinese Holstein dairy cow. Four hundred and seventy dairy cows were use in this study, genomic DNA was extracted from the blood of dairy cow, PCR-RFLP was applied to genotype of these DNA samples. Analysis of Variance (ANOVA) was performed by the General Linear Model (GLM) procedure of SAS 9.13 to identify the association of SNP with milk and reproductive traits. Results showed that SNP in LOC514211 was polymorphic in this herd of dairy cow and was in Hardy-Weinberg disequilibrium, and had significant differences among genotype in milk yield, milk quality and reproductive traits, which were similar with the results of previous GWAS study 
based SNP-Chips. Inconclusion, indicated that this SNP in LOC514211 might be potential markers for both milk and reproductive traits.

Keywords: SNP, LOC514211, milk trait, reproductive trait, dairy cow

\section{INTRODUCTION}

Nowadays, issues about milk production and milk quality becomes the big topic in dairy industry farm. The milk yield and quality are economically important traits in dairy industry. Nevertheless, until now traditional selection method have generally lead to improve milk production and lead to decline in reproduction. This case is consequence of an antagonistic relationship between production and reproduction, selection experiments that increasing genetic merit for production traits is associated with a decline in fertility on the phenotypic scale (Pryce and Veerkamp 2001; Pryce et al., 2004). The negative genetic correlation between production and reproduction of dairy animal at the gene level may be explained by pleiotropic gene effects, linkage, or further complex physiological associations (Veerkamp et al., 2003). While, reproduction also important factor influencing milk yield on dairy animal. It is major trait of cattle and key factor in successful milk production. Good reproduction management will produce high milk production and profit for dairy farm. Reproduction is regularly limiting factor in attempts to increase the milk yield (Novakovic et al., 2011). Some reproduction factor influence milk yield, like Days Open shorter Days Open will increase milk yield, days of first service (DFS), age of calving (AOC) have strong relation, higher DFS, and AOC will increase milk yield. Birth Weight (BW), increase BW will increase milk yield and calving interval $(\mathrm{CI})$, increase $\mathrm{CI}$ will cause in longer lactation period that automatically increase in milk yield (Arbel et al., 2001; Bayram et al., 2009; Novakovic et al.., 2011). Based on this fact, it need to improve genetic selection in order to get high and good milk production without decreasing fertility of dairy animals in order to improve profit in dairy farm industry.

Genetic polymorphisms are playing an increasingly important role as DNA markers in many fields of animal breeding. Single Nucleotide Polymorphism (SNP) is a variation sequence form within genome, SNP often used as genetic marker and as a correlating factor to phenotypic traits and genetic diseases in animal also to detect the significant QTL (Pimentel et al., 2010; Seidel, 2010). SNP provide more accurate information aiding in selection for economically important traits, well established that the quality and quantity of milk yield and quality differ among the species, breeds as well as individuals within a breed (Javed et al., 2011). It is essential to identify SNPs in candidate genes responsible for milk quality and quantity. LOC 514211 is uncharacterized gene. LOC 514211 is protein coding gene type and it's located in chromosome 13 in Bos taurus (NCBI, 2012). Depend on previous study by Junjing (2012) explained that LOC514211 has significant effect on milk production and quality.

The objective of this study was to clarify the association between SNP in LOC514211 gene with milk and reproductive traits in Chinese Holstein dairy cows, which were identified from Chinese and British dairy cows based on 60k SNP-Chip and GWAS in previous study (Junjing, 2012).

\section{MATERIALS AND METHODS}

This study was conducted at Biomolecular and Animal Science Laboratory in Huazhong Agricultural University. Four hundred seventy head of Chinese Holstein Dairy Cows were used in this study. Genomic DNA was extracted from blood of cow using standard phenol chloroform of Sambrook method (Sambrook et al, 1989), SNP genotyping was performed using PCR-RFLPs, and association study was carried out using SAS software.

Primer design: a pairs of primers were designed using the PRIMER PREMIER 5.0 software (Premier, Canada) to amplify fragment with this SNP (rs 42688595) of LOC514211 gene based on the genomic DNA sequence of Holstein cattle. Forward primer: ACGGTGTTTGGGT TCCTG $18 \mathrm{bp}$ and Reverse primer: CTGT CTTGCCCTGTTTCG 18bp. Length of amplification product was $352 \mathrm{bp}$ with temperature annealing $58.8^{\circ} \mathrm{C}$. Restriction enzyme used in this research was TaqI.

Amplification: the $20 \mathrm{~mL}$ PCR mixed reagents included $2 \mu \mathrm{L} 10 \times$ buffer, $0.6 \mu \mathrm{L} 10$ $\mathrm{mM}$ dNTPs, $0.4 \mu \mathrm{L} 10 \mu \mathrm{M}$ of each primer, $2.0 \mu \mathrm{L}$ 
$50 \mathrm{ng} / \mu \mathrm{L}$ genomic DNA, $0.3 \mu \mathrm{L} 5 \mathrm{U} / \mu \mathrm{L}$ Taq DNA polymerase (TaKaRa, China), and $14.3 \mu \mathrm{L} \mathrm{ddH}_{2} \mathrm{O}$. PCR was performed using react program: $94^{\circ} \mathrm{C}$ for $10 \mathrm{~min}$, following by 36 cycles of $94^{\circ} \mathrm{C}$ for 45 $\mathrm{s}$, annealing $58.8^{\circ} \mathrm{C}$ for $45 \mathrm{~s}$ and $72^{\circ} \mathrm{C}$ for $45 \mathrm{~s}$, a final extension at $72^{\circ} \mathrm{C}$ for $25 \mathrm{~min}$ and the last step at $15^{\circ} \mathrm{C}$ for $10 \mathrm{~min}$. PCR products evaluated by electrophoresis on $2 \%$ of agarose gels.

\section{Genotyping}

The PCR products were digested for 5-6 hours it was incubated in $65^{\circ} \mathrm{C}$ at incubator using TaqI restriction enzyme. The digested reaction of $5 \mu \mathrm{L}$ PCR products was carried out in $11 \mu \mathrm{L}$ system, including $5 \mu \mathrm{L}$ PCR products, $3 \mu \mathrm{L}$

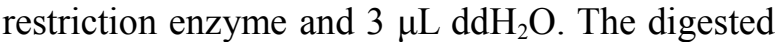
products of this SNP were visualized on $2 \%$ of agarose gel.

\section{Statistics of Association Analysis}

Observed variable milk and reproductive traits included milk fat rate $(\%)$, milk protein rate $(\%)$, total milk yield, total fat yield, total protein yield, and 305 days milk yield. Variable reproduction: days to first service, days open, birth weight, calving interval, and age of calving. Observed variables were used for determining the association between SNP genotypes and these above traits in dairy cows.

Frequency of SNP was calculated according to Nei (1972):

$$
\mathrm{q}_{1}=\left[2 \mathrm{x} \sum \mathrm{n}_{\mathrm{ii}}+\sum \mathrm{n}_{\mathrm{ij}}\right] / 2 \mathrm{n}
$$

Where:

$\mathrm{q}_{1}=$ frequency of gene- $\mathrm{i}$

$\mathrm{n}_{i i}=$ number of individuals to genotype $\mathrm{A}_{i} \mathrm{~A}_{i}$

$\mathrm{n}_{i j}=$ number of individuals to genotype $\mathrm{A}_{i} \mathrm{~A}_{j}$

$\mathrm{n}=$ number of sample

Frequencies of distribution of alleles of gene to know Hardy Weinberg Equilibrium within the herds was compared using the Chi-square test using excel:

$$
X^{2}=\sum_{i=1}^{n} \frac{\left(O_{i}-E_{i}\right)}{E_{i}}
$$

Where:

$\mathrm{X}^{2}=$ Chi square test

$\mathrm{O}_{\mathrm{i}}=$ number of individual given phenotype observed

$E_{i}=$ number of that phenotype expected from null hypothesis

The effects of SNP genotypes on the milk and reproductive traits of cows were analyzed using the General Linear Model (GLM) procedure from SAS 9.13, milk and reproductive data of different genotypes were subjected to Analysis of Variance (ANOVA) using the software. A value of $\mathrm{P}<0.05$ was regarded as significant. The statistical model used was:

$$
\mathrm{Y}_{\mathrm{ijk}}=\mu+\mathrm{h}_{\mathrm{i}}+\mathrm{P}_{\mathrm{j}}+\mathrm{Q}_{\mathrm{k}}+\mathrm{N}_{\mathrm{l}}+\mathrm{e}_{\mathrm{ijkl}}
$$

Where

Yijk = the analyzed trait of cow

$\mu=$ general mean;

$\mathrm{h}_{\mathrm{i}}=$ farm effect

$P_{j}=$ year and season effect

$\mathrm{Q}_{\mathrm{k}}=$ parity effect

$\mathrm{N}_{\mathrm{l}}=$ genotype effect

$\mathrm{e}_{\mathrm{ijkl}}=$ random error effect

\section{RESULTS}

\section{Identification Genotypes of the SNP (rs 42688595) in LOC514211 Genes}

PCR-RFLP with TaqI restriction enzyme was applied to genotype of SNP, and there were three genotypes of this SNP, those were TT (334bp), CC (97bp/273bp) and TC ( 97bp/ 273bp/334bp) in this 470 dairy cows (Figure 1). RFLP (Restriction Fragment Length Polymorphism) is a difference in homologous DNA sequences that can be detected by presence of fragment different length after digestion of DNA samples in question with specific restriction endonucleases. Thus, revealing a unique blotting pattern characteristic to a specific genotype at specific locus. RFLP probes usually have typically such as: short, single or low copy genomic DNA or cDNA clones (Karimi et al., 2009; Meignanalakshmi and Nainar, 2009).

\section{Genotype and Allele Frequencies of SNP}

Frequency of allele $\mathrm{T}(0.62)$ was higher than allele $\mathrm{C}(0.38)$. The TT genotype was the highest frequency in the population $(0.46)$, then followed by TC $(0.33)$ and $\mathrm{CC}(0.21)$. The population at this restriction site was in disequilibrium tested Hardy-Weinberg equilibrium using $\mathrm{X}_{2}$ test to get equilibrium and disequilibrium from all SNPs of all candidate gen (Table 1). It is mean that at least one of standard assumption for test might be violated, and those assumptions are: non overlapping generation with random matting, no mutation, no selection and no migration (Wang et al., 2011; Pitchard, 2013). 
Table 1. Genotype and Allele Frequencies of SNP in Dairy Cows

\begin{tabular}{ccccc}
\hline $\begin{array}{c}\text { Candidate } \\
\text { Gene }\end{array}$ & Number & $\begin{array}{c}\text { Genotype } \\
\text { Frequencies }\end{array}$ & $\begin{array}{c}\text { Allele } \\
\text { Frequencies }\end{array}$ & Chi-square test \\
\hline \multirow{3}{*}{ LOC514211 } & $\mathrm{TT}=0.46$ & & \\
& 427 & $\mathrm{TC}=0.33$ & $\mathrm{~T}=0.62$ & Disequilibrium (37.210) \\
& & $\mathrm{CC}=0.21$ & & \\
\hline
\end{tabular}

\section{The Association of the SNP in LOC514211 Gene with Milk Yield}

The SNP effects in LOC514211 on milk yield is presented in Table 2. Table 2 shows that there was a significant effect of SNP on total milk yield (TMY) in Lactation 2 of dairy cows. The cows with TC genotype produced higher TMY than that of TT and CC genotype $(\mathrm{P}<0.05)$, where $\mathrm{TC}$ was dominant genotype in higher TMY. The previous study showed that LOC514211 had significant effect $(\mathrm{p}<0.001)$ on TMY (Junjing, 2012). TC genotype of LOC514211 gene have similar result with previous study, it is have significant result in higher total milk yield. However, SNP in LOC514211 did not have significant effect on 305 days in milk. This study shows that milk yield $\mathrm{TC}>\mathrm{TT}$, it means that cows with TC genotype have higher milk yield than TT genotype it can be postulated that TC genotype can be used as genotype marker in order to get high milk yield.

\section{The Association of the SNP in LOC514211 Gene with Milk Quality}

Table 3 shows that SNP in LOC514211 had a significant effect on Total Milk Fat $(\mathrm{P}<0.05)$ in Lactation 1. Cows with TT genotype had significant higher total milk fat (TMF) than that of CC genotype $(\mathrm{P}<0.05)$, where TT were dominant genotype related with higher TMF. This result confirm previous study that LOC514211 had a significant effect $(\mathrm{P}<0.001)$ on TMF (Junjing, 2012). However, SNP in LOC514211 did not have significant effect on other milk quality traits.

These results indicated that this SNP may be a potential marker of TMY and TMF. TT have significant result in higher total milk fat. It means that this study confirm previous study that done by Junjing (2012) stated that LOC514211 has significant effect on total milk yield and total mil fat. There are no other study explain the effect of

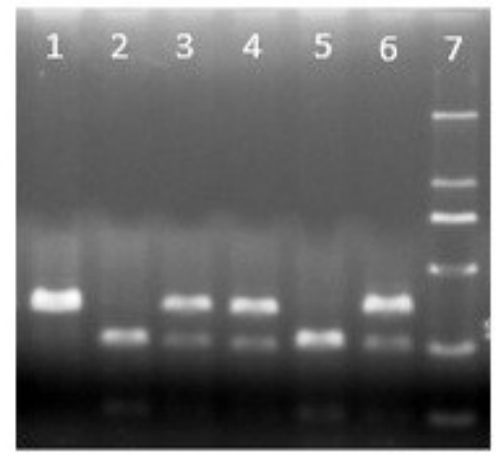

Figure1. Three genotypes of SNP in LOC514211 gene. 1: TT genotype; 2, 5: CC genotype; 3, 4, 6: TC genotype; 7 marker DL2000

LOC514211 candidate gene with milk yield and quality. These results hinted that this SNP may be a potential marker of TMY and TMF

\section{The Effect of SNP in LOC514211 Gene on Reproductive Traits}

In Table 4, the cows with TC genotype had significant more day to first service (DFS) than TT genotype $(\mathrm{P}<0.05)$ in $1^{\text {st }}$ parity. In second parity, while these cows with TT genotype had more DFS than TC genotype $(\mathrm{P}<0.05)$. However, there was no significant effect on the DFS in previous GWAS study (Junjing, 2012). The opposite result between first and second parity may be happen because cows with TT genotype had longer calving interval than TC genotype in second lactation, while in the first parity cows with TC genotype had longer calving interval than TT genotype. This condition maybe influences opposite result between first and second lactation on DFS trait.

Table 4 also shows that there were significant different effects of SNP on birth 
Table 2. Effect of SNP in LOC514211 Gene on Milk Yield (kg)

\begin{tabular}{ccrcc}
\hline Trait & Genotype & No. & Lactation 1 & \multicolumn{1}{c}{ Lactation 2 } \\
\hline \multirow{3}{*}{ 305 DIM } & TT & 90 & $7411.63 \pm 107.45$ & $8287.58 \pm 240.76$ \\
& CC & 197 & $7383.72 \pm 79.49$ & $8102.2 \pm 110.25$ \\
& TC & 141 & $7279.52 \pm 96.76$ & $7944.26 \pm 104.36$ \\
Total Milk Yield & TT & 90 & $8732.70 \pm 109.13$ & $9244.41 \pm 345.08^{\mathrm{a}}$ \\
& CC & 197 & $8858.27 \pm 93.27$ & $10051.05 \pm 278.95^{\mathrm{a}}$ \\
& TC & 141 & $8684.37 \pm 111.36$ & $10923.54 \pm 249.78^{\mathrm{b}}$ \\
\hline
\end{tabular}

Different superscript in the same column at a trait indicate significantly different $(\mathrm{P}<0.05) ; 305$ DIM: 305 Days in Milk (kg), No: Number of sample (head).

Table 3. Effect of SNP in LOC514211 Gene on Milk Quality

\begin{tabular}{ccrcr}
\hline Trait & Genotype & No. & Lactation 1 & Lactation 2 \\
\hline Fat Milk Rate & TT & 90 & $3.73 \pm 0.04$ & $3.72 \pm 0.06$ \\
$(\%)$ & CC & 197 & $3.69 \pm 0.03$ & $3.64 \pm 0.03$ \\
& TC & 141 & $3.75 \pm 0.02$ & $3.63 \pm 0.04$ \\
Total Milk Fat & TT & 90 & $351.48 \pm 4.65^{\mathrm{b}}$ & $506.32 \pm 5.32$ \\
(kg) & CC & 197 & $329.12 \pm 4.49^{\mathrm{a}}$ & $525.47 \pm 6.65$ \\
& TC & 141 & $342.34 \pm 6.46^{\mathrm{ab}}$ & $497.02 \pm 13.64$ \\
Protein Milk Rate & TT & 90 & $3.13 \pm 0.02$ & $3.07 \pm 0.03$ \\
$(\%)$ & CC & 197 & $3.13 \pm 0.02$ & $3.08 \pm 0.02$ \\
& TC & 141 & $3.12 \pm 0.02$ & $3.06 \pm 0.02$ \\
Total Milk Protein & TT & 90 & $292.14 \pm 9.01$ & $308.62 \pm 14.11$ \\
$(\mathrm{~kg})$ & CC & 197 & $297.69 \pm 7.96$ & $313.1 \pm 7.37$ \\
& TC & 141 & $291.01 \pm 4.74$ & $327.91 \pm 7.92$ \\
\hline
\end{tabular}

Different superscript in the same column at a trait indicate significantly different $(\mathrm{P}<0.05)$; No: Number of sample (heads).

weight (BW) in $1^{\text {st }}$ and $2^{\text {nd }}$ parity. Cows with $\mathrm{CC}$ genotype had heavier BW of their calves than TC genotype $(\mathrm{p}<0.05)$. The amount of milk produced by the cow increases with advancing lactations (age). This is because of part to increase in body weight, which results in a larger digestive system and a larger mammary gland for the secretion of milk and also due to the effects of recurring pregnancies and lactations. Data on milk production with cows suggestwd that $20 \%$ of increasing in milk production is due to increasing in body weight and $80 \%$ to the effects of recurring pregnancy and lactations (Dairy production, 2012).

Cows with TT genotype had higher ages of calving (AOC) than CC genotype. SNPs from LOC 514211 candidate genes did not have significant effect on AOC in previous research that has been conducted through $60 \mathrm{~K}$ SNP microarrays (Junjing, 2012). In the present study 
Table 4. The Effect of SNP in LOC514211 Gene on Reproductive Traits

\begin{tabular}{|c|c|c|c|c|c|c|c|}
\hline Trait & Genotype & No. & Parity 1 & No & Parity 2 & No & Parity 3 \\
\hline \multirow{3}{*}{ DFS } & TT & 72 & $120.40 \pm 5.73^{\mathrm{a}}$ & 72 & $123.27 \pm 9.50^{\mathrm{b}}$ & 72 & $108.34 \pm 6.06$ \\
\hline & $\mathrm{CC}$ & 157 & $132.14 \pm 4.80^{\mathrm{ab}}$ & 157 & $116.48 \pm 5.38^{\mathrm{ab}}$ & 157 & $110.65 \pm 4.37$ \\
\hline & $\mathrm{TC}$ & 109 & $138.78 \pm 6.34^{\mathrm{b}}$ & 109 & $106.11 \pm 3.80^{\mathrm{a}}$ & 109 & $112.33 \pm 6.60$ \\
\hline \multirow{3}{*}{ DO } & TT & 72 & $203.89 \pm 16.54$ & 72 & $141.89 \pm 9.46$ & 72 & $160.56 \pm 16.46$ \\
\hline & $\mathrm{CC}$ & 157 & $189.58 \pm 8.39$ & 157 & $139.32 \pm 6.68$ & 157 & $174.42 \pm 11.91$ \\
\hline & $\mathrm{TC}$ & 109 & $195.93 \pm 9.86$ & 109 & $143.30 \pm 8.44$ & 109 & $154.46 \pm 12.26$ \\
\hline \multirow{3}{*}{ BW } & TT & 72 & $37.00 \pm 0.40^{\mathrm{a}}$ & 72 & $37.96 \pm 0.50^{\mathrm{b}}$ & 72 & $37.89 \pm 0.71$ \\
\hline & $\mathrm{CC}$ & 157 & $38.10 \pm 0.25^{\mathrm{b}}$ & 157 & $37.95 \pm 0.40^{\mathrm{b}}$ & 157 & $38.05 \pm 0.47$ \\
\hline & $\mathrm{TC}$ & 109 & $37.19 \pm 0.44^{\mathrm{a}}$ & 109 & $36.18 \pm 1.15^{\mathrm{a}}$ & 109 & $38.11 \pm 0.42$ \\
\hline \multirow{3}{*}{$\mathrm{CI}$} & TT & 72 & $425.12 \pm 12.31$ & 72 & $416.70 \pm 8.96$ & 72 & $414.07 \pm 16.99$ \\
\hline & $\mathrm{CC}$ & 157 & $438.83 \pm 6.54$ & 157 & $400.49 \pm 6.20$ & 157 & $414.74 \pm 7.98$ \\
\hline & $\mathrm{TC}$ & 109 & $441.67 \pm 7.31$ & 109 & $409.04 \pm 7.17$ & 109 & $408.33 \pm 13.14$ \\
\hline \multirow{3}{*}{$\mathrm{AOC}$} & $\mathrm{TT}$ & 72 & $28.78 \pm 0.44$ & 72 & $44.49 \pm 0.83$ & 72 & $59.45 \pm 1.19^{b}$ \\
\hline & $\mathrm{CC}$ & 157 & $29.06 \pm 0.29$ & 157 & $44.37 \pm 0.49$ & 157 & $57.32 \pm 0.49^{\mathrm{a}}$ \\
\hline & $\mathrm{TC}$ & 109 & $28.50 \pm 0.29$ & 109 & $44.90 \pm 0.50$ & 109 & $57.49 \pm 0.69^{\mathrm{ab}}$ \\
\hline
\end{tabular}

Different superscript in the same column at a trait indicate a significantly different at $(\mathrm{P}<0.05)$. DFS: Day to First Service (days), DO: Days Open (days), BW: Birth Weights (kg), CI: Calving Interval (day), AOC: Ages of Calving (months)

it can be postulated that TT genotype can be used as genetic marker in order to get higher AOC. There were no early reports or research available to compare or contrast the present study. Shergojry et al., 2011, established that age of calves at first calving depends mainly on age at first conception. Age of heifers at first conception has impact on milk production in the first lactation, also on long lactation period and to increase quantity of milk yield (Bayram et al., 2009; Novakovic et al., 2011). Optimal age of heifers at first calving, and based of aspect of maximum economical gain, should be 23 to 24 months. In the function of maximum use of genetic potential for production of milk and decrease of costs of rearing, recommendation was that average age of heifers at first calving should be $<24$ months and body mass of $>560 \mathrm{~kg}$ after calving with 24 months. First calving at the age of $<23$ months caused lower yields of milk and milk components in the first lactation and more reproductive problems. However, increase of age at fist calving to $>24.5$ months did not improve the milk yield, reproduction or health of first calving cows (Novakovic et al., 2011).

The SNP genotype from LOC 514211 were not significant different in calving interval (CI). This result in line with previous study that SNP from LOC 514211 candidate genes did not have significant effect on reproduction trait such as days open (DO) in previous research that has been conducted through $50 \mathrm{~K}$ SNP microarrays (Junjing, 2012). In previous study of Arbel et al. (2001), extended CI will make higher milk yield and improving profit to dairy farm industry. Because when CI was extended, the lactation period will longer, this fact will increase the TMY of dairy animal that automatically will increase profit of dairy farm industry. Cows with higher production during current or previous lactation had longer intervals to first service (Hill, 2010). Based on this result it hinted that this SNP in 
LOC514211 may be potential marker of Day to First Service, Birth Weight of calves and AOC.

\section{CONCLUSION}

SNP in LOC514211 gene was polymorphic in dairy cows in this study. SNP genotypes of candidate gene LOC514211 had a significant effect on milk and reproductive traits. The study presented the similar results that found in previous SNP-Chip and GWAS study. These results indicated that SNP in LOC514211 gene might be potential marker of both milk and reproductive traits.

\section{ACKNOWLEDGMENTS}

Financial assistance from Chinese projects from the Chinese government (2014030709020305, 2013070204020045, B12005 and the Huanghe Yingcai Project) and EU FP7 projects (PIIF-GA-2012-328205, PIIFR-GA2012-912205 and FP7-KBBE-2013-7-613689) are greatly appreciated. Ministry of Education and Culture, Republic of Indonesia which provided financial support through the scholarship and financial support from "Beasiswa Unggulan (BU)" scholarship program from Planning and Overseas Cooperation Bureau (BPKLN) Ministry of Education and Culture, Republic of Indonesia.

\section{REFERENCES}

Arbel, R., Y. Bigun, E. Ezra, H. Sturman and D Hojman. 2001. The effect of extended calving intervals in high-yielding lactating cows on milk production and profitability. J. Dairy Sci. 84(3):600-8.

Bayram, B., M. Yanar and O. Akbulut. 2009. The effect of average daily gain and age at first calving on reproductive and milk production traits of Brown Swiss and Holstein Friesian cattle. Bulgarian J. Agri Sci. 15(5):453-462.

Dairy Production 342-450A, 2012. Milk Yield and Composition. Source: http:// dairy production. google.com). Accessed Date: $20^{\text {th }}$ March 2012.

Hill, R. A., 2010. Evaluation of Single Nucleotide Polymorphisms Associated with Fertility and Production Traits In Holstein and MultiGenerational Angus Females. Faculty of the Louisiana State University and Agricultural and Mechanical College. B.S., Louisiana State University. Thesis.
Javed, R., S. K. Gautam, R. K. Vijh and M. S. Tantia. 2011. Six novel pcr-rflp loci in milk quality candidate genes in bubalus bubalis. Int. J. Livestock Prod. 2(6):79-83.

Junjing, W. 2012. Genome Wide Association Study of Reproduction and Milk Production Traits in Dairy Cows And Water Buffalo. Huazhong Agricultural University. Dissertation.

Karimi, K., M. T. B. Nasiri, J. Fayyazi, K. H. Mirzadeh and H. Roushanfekr. 2009. Allele and genotype frequencies of $\beta$-lactoglobulin gene in Iranian Najdi cattle and buffalo populations using pcr-rflp. african. J. Biotechnol. 8(15): 3654-3657.

Meignanalakshmi, S and A. M. Nainar. 2009. Pcrrflp analysis of beta-lactoglobulin gene in Murrah buffaloes. J. Vet. Anim. Sci. 5(5): 194-197.

NCBI. 2011. LOC514211 uncharacterized LOC 514211. http://www. ncbi.nlm. Nih.Gov/Gene 1529591). Accessed date: November 12, 2011.

Nei, M. 1972. Genetic distance between population. Amer. Nat. 106(949): 283-292.

Novaković, Ž., Lj. Sretenović, S. Aleksić, M. M. Petrović, V. Pantelić, and D. Ostojić-Andrić. 2011. Age at first conception of high yielding cows. Biotech. Anim. Husbandry 27(3):1043-1050.

Pimentel, E. C. G., S. Bauersachs, M. Tietze, H. Simianer, J. Tetens, G. Thaller, F. Reinhardt. E. Wolf and S. König. 2010. Exploration of relationships between production and fertility traits in dairy cattle via association studies of snps within candidate genes derived by expression profiling. Anim. Genet. 42(3):251-262.

Pitchard, D. E. 2013. Calving Interval, Milk Production and Profitablity. www. Cals.nsu.edu. Accessesed Data: $20^{\text {th }}$ March 2013.

Pryce, J. E. and R. F. Veerkamp. 2001. The incorporation of fertility indices in genetic improvement programmes. BSAS Occasional Publication. 26(1): 237-50.

Pryce J. E., M. D. Royal., P. C. Garnsworthy and I.L. Mao. 2004. Fertility in the highproducing dairy cow. Livestock Prod. Sci. 86(1):125-35.

Sambrook, J., E. F. Fritsch and T. Maniatis. 1989. Molecular Cloning: A Laboratory Manual. $2^{\text {nd }}$ edition. Cold Spring Harbor. Lab. Press. 


\section{USA.}

Seidel, G. E. J. 2010. Brief introduction to wholegenome selection in cattle using single nucleotide polymorphisms. Reprod Fertile Dev. 22(1): 138-144.

Shergojry, S. A., B. A. Ganayi, K. P. Ramesha, K. Rengarajan, G. V Srihari, D. N. Das and M. A. Kataktalware. 2011. Association of single nucleotide polymorphisms (snps) of hsp90aal gene with reproductive traits in Deoni cattle. Int.J.Livest.Res. Online 1(1):17-29.
Veerkamp, R.F., B. Beerda and Van De Lende. 2003. Effects of genetic selection for milk yield on energy balance, levels of hormones, and metabolites in lactating cattle, and possible links to reduced fertility. Livest. Prod. Sci. 83(2-3): 257-75.

Wang, C., M. Liu, Q. Li, Z. Ju, J. Huang, J. Li, H. Wang and J. Zhong. 2011. Three novel singlenucleotide polymorphisms of Mbl1 gene in Chinese Native cattle and their associations with milk performance traits. Vet. Immunol. Immunopathol. 139(2-4): 229-236. 